\title{
Application of Team of Accelerated Instruction Cooperative Learning with Problem Solving
}

\author{
Dyan Eka Pamungkas \\ Department of Elementery Education \\ STKIP Bina Insan Mandiri \\ Surabaya, Indonesia \\ fiandyan45@gmail.com
}

\author{
Sukarman, Sri Wahyu Widayati \\ Department of Javanese Language Education \\ Universitas Negeri Surabaya \\ Surabaya, Indonesia
}

\begin{abstract}
This research aims to improve the activity and learning outcomes of science through the application of cooperative learning type of Team Accelerated Instruction (TAI) with problem solving method on the fifth grade students. Based on preliminary observation at elementary school researchers found problems on learning science in the fifth grade. Teachers have not used varied models and learning media, so it made the passive students and have not spirit to follow the learning process. This type of research is a classroom action research was conducted through planning, action, observation, and reflection. The sample of the research is on the fifth grade of 30 students. Based on activity results and student learning results can be concluded that TAI learning models can improve activities and outcomes of science, especially thermal energy material and its sound and properties. Based on the results of the study suggested in class $\mathrm{V}$ teacher to use TAI model, because by using TAI model can make students active and can improve the results of science study. This is evident from the results of students ' activities and learning outcomes. Besides, TAI models can also motivate students to learn and work on questions, and students can play an active role during the learning process.
\end{abstract}

Keywords-activities; cooperative learning type of TAI; learning outcome; problem solving

\section{INTRODUCTION}

Learning or learning is a process of interaction (a reciprocal relationship) between teachers and students and the elements in them. Learning is part of education, which in itself is supported by learning elements learning objectives, learning materials, infrastructure facilities, situations or learning conditions, learning environment, learning methods, learning models, and learning evaluation. All of these learning elements influence the success of the teaching and learning process to improve student learning outcomes.

Learning is a process and activity that is always done and experienced by man. In accordance with the principle of lifelong learning that people learn from the beginning in the womb to the grave. Teachers as educators need to develop learning that fits the demands of the global era. Paradigm change from teaching or instruction focusing on teacher's activity (teacher centre) is now turning towards learning that focuses on student's centre. Learning Science today is more emphasis on learning critical thinking skills, creative and capable of solving problems. This is stated in regulation of the Minister of National Education number 22 year 2006 mentioned that the science subjects aims to Learners know the concept in relation to people's lives with their environment, being able to think logically, critically, Solve problems, skilled in social life, have social and humanitarian value, able to communicate and compete [1].

The low quality of human resources today due to the lack of education. It can also be seen from various indicators including the results of the study Trends in International Mathematics and Science Study (TIMSS), results show the average of Indonesia's student score is below the international mean score is below the international average score. The lack of Indonesian scores due to the learning process of school science multiple choice and math problems that are given to learners are not in the form of problem solving questions. In contrast to the problems given to science literacy or TIMSS that better prioritizes the problem-solving process compared with the end result.

Learning science in schools especially in elementary school is expected to be a vehicle for learners to study themselves and the environment, as well as further development prospects in applying them to daily life. This is in accordance with the understanding of natural sciences related to how to find out about nature systematically. So, that science is not only about mastering the knowledge set in the form of facts, concepts, or principles, but also a process of discovery. An important aspect that teachers should be aware of in the implementation of learning science in elementary school is to engage students actively in learning to develop his thinking skills. Learning science begins with the conception/knowledge students who are relevant to what will be learned. Subsequent learning activities are designed through a variety of real natural. Real experience activities with this nature can be done in a class or laboratory with a learning aids or done directly in the outdoors. Through real activity with this nature, students can develop process skills and scientific attitudes such as observe, try, conclude the outcome of the activity and communicate the conclusion of its activities. Science study conducted by raising problems in the real world experienced by children will be more attractive to 
children, so that children are actively involved in developing their skills.

The problem arises is that the education is still dominated by the view that knowledge as a device of facts should be memorized, including science subjects. On the other hand, there are many facts that the teacher mastered the subject matter well but could not conducting well-learning activities. This is because learning is not based on specific learning models so that Student-generated learning outcomes. Education can undergo better direction to be needed renewal. One of the renewed efforts in the educational world is the renewal in the learning model used. Learning models are said to be relevant if they are able to reach learning objectives.

Learning models are the means or presentation techniques teachers use in the learning process to achieve learning objectives. The selection of learning models will determine the success of teaching learning. Therefore, a teacher must be able to make combinations or variations in choosing the right learning model to facilitate students to receive subject matter

TAI Type Cooperative Learning Model was developed by Robert E. Slavin and friends. TAI is cooperative learning, where students are placed in small groups (4 to 5 students) heterogeneous and followed by individual assistance for students who need it. Before the group formed students were taught how to cooperate in a group, students were taught to be good listeners, discuss, encourage other friends to cooperate, appreciate the opinions of other friends and so on [2].

TAI-Type Cooperative learning measures 1) placement test is the initial test to students to place students in groups, 2) teaching group, namely the giving of the teacher a brief material, 3) a study team that is the stage of learning action that must be played in the group and teachers provide assistance individually, 4) whole class unit namely the material giving back by the teacher with problem solving strategy, 5) fact test is the implementation of the final test, 6) team scoring and team recognition of the scoring and appreciation of the group's work.

While the problem-solving method is a process or individual effort to respond, or overcome obstacles or constraints when an answer or method of answer is not yet apparent [3]. In this study the troubleshooting steps include: Understanding Problems, planning solutions, implement the plan, and re-examine the completion/answer. Learning activities are activities that involve all aspects psychophysics learners, both physically and spiritually so that their behaviour acceleration occurs quickly, precise, easy and correct, whether related to cognitive, affective, or psychomotor aspects [4]. Learning outcomes are the abilities that students have had after receiving their learning experience [5]. Bloom classifying the types of learning outcomes there are three namely learning outcomes of cognitive, affective, and psychomotor.

Cooperative learning Model of Team-type Accelerated Instruction (TAI) with problem solving method is chosen in this study because through the learning model can improve student activity and learning outcomes through cooperation in heterogeneous groups. Academically intelligent students can become peer tutors towards students whose academic skills are moderate or low, and students who have high abilities can move on to the next subject without having to wait for the submission of their friends. So, with this learning model can foster the spirit of students in learning.

In everyday life students inevitably face various issues of both personal problems, with friends, and problems completing the tasks given by the school. Social issues cover the situation of problems related to cannot easily be solved in everyday life as those who do not have a specific is that individual attitudes cannot solve the problem [6].

Based on preliminary observations done at SDN Sambirejo III Nganjuk showed that teachers in conducting science study have not used the varied learning methods and media. The observation also shows that learning is still oriented to textbooks, the students are passive, the classes are quiet and tidy. It greatly affects student learning outcomes.

It is supported with data from the student science study results in the first semester of lesson $2017 / 2018$ as many as 24 students from 30 students or at $80 \%$ is still under the minimum submission criteria (KKM) set of 75 . By looking at the results of learning data on the implementation of learning science need action to increase the activity and learning outcomes of students.

TAI type cooperative learning model with problem solving skills in this study placement test, teams, teaching group, student creative, team study, whole class unit, team scores and team recognition, and fact test. So, it is carried out systematically and combined with the problem-solving skills provided by the teachers and students made through the worksheet.

Thus, TAI type cooperative learning model with problem solving in this study can be provide convenience for students in Understand difficult subject matter. So, students can achieve maximum learning outcomes. Based on the description, so it is very good to be developed and researched about TAI type cooperative learning model with problem solving for make it easier for students to understand lessons, achieving maximum and optimal learning outcomes through this study.

Based on the problems described above the research question is as follows (1) How to implement TAI-type cooperative learning with problem methods solving can increase student activity in SCIENCE subjects in the class V of SDN Sambirejo III Nganjuk? (2) How is the implementation of TAI with cooperative learning method problem Solving can improve student learning outcomes in science subjects in the class V SDN Sambirejo III Nganjuk?

Based on the problem, the purposes of this research are (1) To describe and analyze student activity in science class $\mathrm{V}$ SDN Sambirejo III Nganjuk by implementing TAI type Cooperative learning with the problem solving method. (2) To analyze the implementation of TAI-type cooperative learning with the problem-solving method can improve student learning outcomes in SCIENCE class V SDN Sambirejo III Nganjuk. 


\section{METHODS}

The type of research conducted by researchers is research conducted by researchers is the Classroom Action Research. Classroom Action Research is a study of the social situation of the intention to improve the quality. Enhanced variables in this class action study are the activities and outcomes of student learning on natural resource materials and human activities. Action variables to be used to improve student activity outcomes and learning outcomes of natural resource materials and human activities is the implementation of TAI type cooperative learning with the problem-solving method. The subject of this study is a student at the V-class of SDN Sambirejo III Nganjuk with a total of 30 students consisting of 17 sons and 13 students.

Classroom Action Research Follow a cycle or recycling process from planning, action, observation and reflection (contemplation, selection, and evaluation). Classroom action research was implemented using a cycle modification model developed by Kemmis and Taggart. The stages of action are depicted in the following chart [7], [8].

This class action research is planned to consist of several cycles and is terminated if it is in accordance with the success criteria. Each cycle consists of two learning meetings. This research procedure from the initial study then continued the stages in cycles that included planning, action, observation and reflection. After the stage activities in the completed cycle will be held revisions are used to determine the action plan in the next cycle. The data collection techniques in this study are observations and tests. The research instrument is an observation sheet of student activity and a test sheet of learning outcomes. The data analysis techniques used are qualitative and quantitative [9].

\section{RESULTS AND DISCUSSION}

Learning models are one of the factors that can affect student learning outcomes. The Learning Model is a conceptual framework depicting systematic procedures for organizing learning experiences to achieve specific learning objectives and serve as teacher guidance in designing and implementing learning. The more precise the teacher chooses the learning model, the more effective it is to achieve appropriate and precise learning objectives with regard to learning objectives, characteristics of students ' development, students ' needs, subject matter, and learning resources available [10].

Learning can be viewed from two angles, first learning is seen as a system, learning consists of a number of organized components, such as learning objectives, learning materials, strategies and learning models, learning media or props, organizing classes, learning evaluation, and follow-up learning (remedial and enrichment). Secondly, learning is seen as a process, learning is a series of efforts or teachers ' activities in order to make students learn. The teaching learning process is influenced by two factors. The first factor is the factor that comes from within the student (internal factor) and the second factor is a factor that comes from outside the student (external factor). Proper use of learning models greatly affects the success of the learning process. However, there is a fact that there are still many teachers who use the lecture model in the process of learning [11].

Nowadays, learning science in elementary school is still using conventional learning model characterized by teacher lecture activities so that learning process is still centred on the teacher. Student activities record the material already in the textbook, as well as teacher talks more dominating in delivering learning materials. This situation causes a monotonous and boring science study where students play a subject of passive learning in the classroom [12].

The study consisted of three cycles. On the implementation of actions expected to increase activity and student learning outcomes in the study of SCIENCE with the implementation of TAI-type cooperative learning with problem solving. From preliminary study pre-tests results showed the level of learning science in the class V students is still in low category. The pretests results showed students who had a value of $\geq 75$ as many as 5 students from 30 students or at $16.67 \%$. The average grade value only reaches 49.78 . Therefore, the need for a solution to improve student learning outcomes are by implementing TAI type Cooperative learning with problem solving so that the activities and outcomes of science grade $\mathrm{V}$ are increased.

The percentage of success of all aspects of the student activity from the I-III cycle can be seen in the following chart.

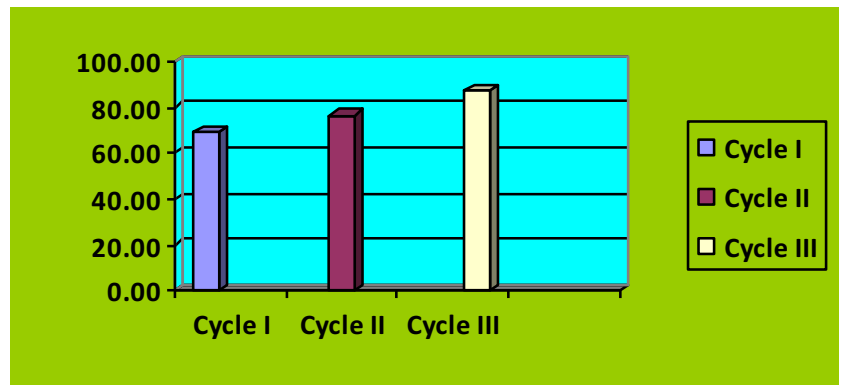

Fig. 1. Graph of student activity submission Cycle I-III

Based on the graph above that the results of observing students ' activity in the study occurred. At cycle I of $69.38 \%$, cycle II is $76.58 \%$ and III cycle is $87.12 \%$. Improvements that occurred in cycle I to cycle II amounted to $7.20 \%$ and from cycle II to cycle III by $10.54 \%$.

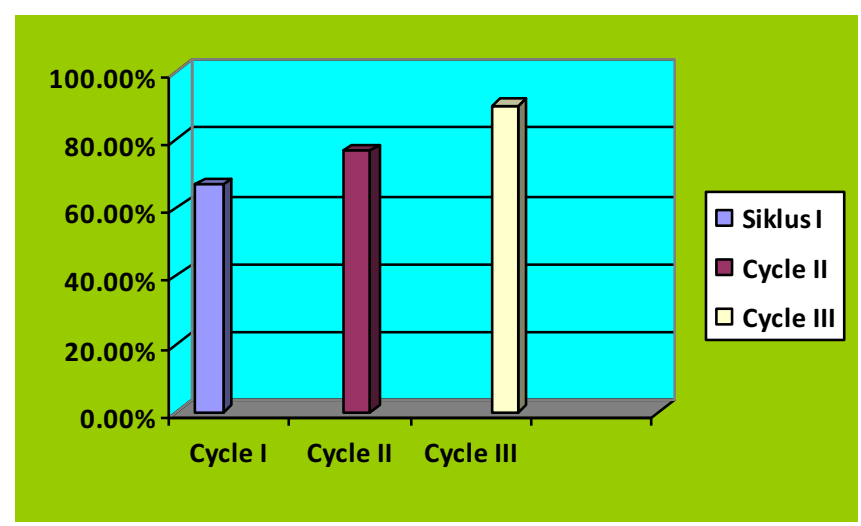

Fig. 2. Chart of improved student learning outcomes in Cycle I-III 
Based on the chart above, shows the level of learning outcome in the classical results of the I cycle of $66.7 \%$ with the average of 76,56 . cycle II is $76.67 \%$ with an average grade value of 81.3. Assessment of learning results showed an increase in cycle II by $10 \%$. The average grade value experienced an increase of 4.74 . cycle III is $90 \%$ with an average grade value of 86.33 . Assessment of learning results showed an increase in cycle III by $13.3 \%$. The average grade value experienced an increase of 5.03 from cycle II. Student activities in the learning process with the implementation of TAI type cooperative learning by problem solving categorized as good Because the applied learning is able to increase student activity, to find concepts, find principles and reduce teacher domination in learning. It is in line with the opinion of which states through cooperative learning of students will be easier to find and understand a difficult concept if they have discussions with their friends [13].

With the implementation of TAI type learning with the problem method solving students' activities can increase, students dare to brainstorm, dare to answer the question, dare to presented the group's work, active in the group discussion to solve the problem. Stating that students are active in physical learning and mentally in terms of submitting the right form of representation, and all that to solve the problem. Based on the results of the research, there are increasing activities and learning outcomes of students on each cycle. The student activity cycle is $69.38 \%$, Cycle II $76.58 \%$ and cycle III increases to $87.12 \%$. The percentage of students ' learning outcomes has also increased. In the I cycle of student learning outcomes as low as $66.7 \%$, cycle II is $76.7 \%$ and on cycle III increases to $90 \%$. With the implementation of TAI type Cooperative learning with problem solving can increase the activity and outcomes of science students at SDN Sambirejo III Nganjuk

\section{CONCLUSION}

TAI-type Cooperative Learning Model with problem solving method can improve the activity and learning results of science. This is demonstrated by the observation analysis of the student activity experienced an increase between the I, II and III cycles. As a follow-up to this research, teachers should use and develop cooperative learning models in science learning. Because with varied discussions the student activity increases and students are happier in learning. We encourage students to be introduced to a variety of learning models and methods, hoping to create a fun learning situation, can enhance students' creativity in discussions and improve their curiosity to think critically and creatively. Teachers should use TAI type cooperative learning model with problem method solving in learning science and other learning because these learning models are proven to increase student activity and learning outcomes.

\section{REFERENCES}

[1] L. K. Ahmadi. Pembelajaran Aktif, Inovatif, Kreatif, Efektif, dan menyenangkan . Bandung: PT Geneshindo, 2011.

[2] Sulistiyowati, dkk. Pengembangan IPA SD. Departemen Pendidikan Nasional: Direktorat Jenderal Pendidikan Tinggi, 2009

[3] S. Harahap, N. Sebayang. Penerapan Pembelajaran Kooperatif Tipe Team Accelerated Instruction (TAI) untuk meningkatkan Aktivitas dan Hasil Belajar Mekanika Teknik Gambar Bangunan SMK Negeri Percut Sei Tuan. Jurnal Education Building. Vol.1, No.1, 2015.

[4] E. Iman. The social problem solving Questionaire Evaluation of Psychometric Properties Among Turkish Primary School Student. Egitim Arastirmalasari-Eurasian Journal of Education Researh issue 52,99, 2013.

[5] N. Baghcheghi, H. R. Koohestani, and K. Rezaei, "A comparison of the cooperative learning and traditional learning methods in theory classes on nursing students'communication skill with patients at clinical settings," Nurse Education Today, vol. 31, no. 8, pp. 877-882, 2013.

[6] Nofriansyah, A. Martiah, R. Vhalery. The Effect Of Learning Model Logan Avenue Problem Solving Heuristic To The Student's Learning Activity. Int J Sci Res Publ 2018;8:279-86.

[7] Nofriansyah, A. Martiah, R. Vhalery. The Effect Of Learning Mode Logan Avenue Problem Solving Heuristic To The Student's Learning Activity. Int J Sci Res Publ 2018;8:279-86.

[8] Y. Riyanto. Metodologi Penelitian Pendidikan Kualitatif dan Kuantitatif. Surabaya: Unesa University Press, 2008.

[9] Robinson. Cooperative Learning and the Academically Talented Student. Arkansas: University of Arkansas, 2013.

[10] R. M. Gillies, "The behaviors, interactions, and perceptions of junior high school students during small-group learning," Journal of Educational Psychology, vol. 95, no. 1, pp. 137-147, 2013.

[11] R. Stevens and R. Slavin, "The Cooperative elementary school: effects on Students achievement, attitudes and social relation," The American Educational Research Journal, vol. 32, pp. 321-351,

[12] C. Suhana. Konsep Strategi Pembelajaran. Bandung: PT Refika Aditama, 2014.

[13] R. Vhalery, Nofriansyah -. Cooperative Learning in the Learning Activity of Students. Int J Sci Res Publ 2018;8:62. 